\title{
Band Gap Reduction and Petal-like Nanostructure Formation in Heavily Ce-doped ZnO Nanopowders
}

\author{
Kamakhya Prakash Misra ${ }^{1}$, Ashok Kumawat ${ }^{1}$, Priyanka Kumari², Susruta Samanta ${ }^{2}$, \\ Nilanjan Halder ${ }^{1}$, Saikat Chattopadhyay ${ }^{1, *}$ \\ ${ }^{1}$ Department of Physics, School of Basic Sciences, Manipal University Jaipur, Jaipur, Rajasthan 303007, India \\ 2 Department of Chemistry, School of Basic Sciences, Manipal University Jaipur, Jaipur, Rajasthan 303007, India
}

(Received 10 January 2021; revised manuscript received 24 March 2021; published online 09 April 2021)

\begin{abstract}
The objective of the present study is to explore the structural and optical behavior of a heavily Cedoped $\mathrm{ZnO}$ nanoparticle system. Well-known chemical sol-gel method is adopted for the synthesis of the nanoparticles and its structural, optical, and morphological features are characterized. XRD and EDX analysis verify the presence of Ce atom in prepared sample. XRD data confirm that the $\mathrm{Ce}^{3+}$ ions occupy the $\mathrm{Zn}^{2+}$ ion sites in the hexagonal $\mathrm{ZnO}$ lattice during doping process. Due to higher doping concentration, excess Ce shows the presence of mixed $\mathrm{CeO}_{2}$ and $\mathrm{Ce}_{2} \mathrm{O}_{3}$ phases in the sample. W-H analysis helps to understand the micro-strain profile in the grown sample. UV-Vis study confirms the band gap shifting in doped samples and Photoluminescence study gives the indication of the presence of defect states which are the reason behind NBE transitions in the samples. Prepared sample were also characterized using FESEM to analyze the surface morphology and nanocrystalline structures.
\end{abstract}

Keywords: ZnO, Rare earth material, Doping, Nanoparticles, Band gap, Photoluminescence.

\section{INTRODUCTION}

The design, synthesis, and use of nanosized materials are one of the important innovations in the last two decades, which found an extensive range of applications in numerous fields including medicine, engineering, technology, catalysis, and environmental remediation. Zinc oxide $(\mathrm{ZnO})$ is one of the most interesting materials from several points of view and the attention in $\mathrm{ZnO}$ is fueled up due to its well-known distinctive properties, viz, high-sensitivity, large specific area, non-toxicity, good photocatalytic activity and a high isoelectric point, which all favor it to be considered as one of the most suitable II-VI semiconductor materials. Due to its wide band gap ( $3.37 \mathrm{eV}$ at room temperature) and large excitonic binding energy (60 meV), some optoelectronic applications of $\mathrm{ZnO}$ overlap with that of GaN, another wide band gap material popularly used in semiconductor industry to generate green, blue ultraviolet, and white light-emitting devices. Based on its simple, low cost, and easy process of synthesis $\mathrm{ZnO}$ becomes a more potential candidate to replace $\mathrm{GaN}$ to design modern semiconductor devices [1-5]. To design $\mathrm{ZnO}$ based nanodevices, one of the most relevant issues is introducing foreign element into pure $\mathrm{ZnO}$ as dopant. Extensive research has been conducted on the electronic and magnetic properties of the $\mathrm{ZnO}$ nanoparticles (NPs) or thin films doped with foreign atoms for nanoelectronic and spintronic device applications. The results satisfactorily show that electronic and magnetic properties of $\mathrm{ZnO}$ nanosystems can be modified by such kind of doping [2, 6-11]. Particularly, doping with optically functional impurities like transition metals (TM) or rare earth (RE) elements permits the extension of the emission wavelength range from visible to the in- frared region. Multi-wavelength and white light emission becomes possible from a single nanodevice by choosing a combination of several suitable dopants or co-dopants [7]. Nowadays the RE elements are more interesting materials as a dopant for $\mathrm{ZnO}$ as $4 f$ shell of $\mathrm{RE}$ elements shows larger magnetic moments and the electrons may intervene the ferromagnetic coupling between the RE ions due to the coupling between $f$ electrons and host $s$ electrons which makes such systems more suitable to design both optoelectronic and spintronic devices [7, 12].

According to Jayachandraiah et al. [12] among all other RE elements, in the recent past, Cerium (Ce) has received much more attention due to its strange optical, luminescence, magnetic, and catalytic properties arising from the availability of the shielded $4 f$ levels with only one electron in the $4 f$ state. Although a rigorous study on optical properties of Ce- $\mathrm{ZnO}$ nanosystems have been started but still the origin of optoelectronic and magnetic properties is remains unsolved. This motivated us to investigate the influence of Ce doping in $\mathrm{ZnO}$ NPs to understand the optical and electronic properties in a systematic way to conclude its use in preparing modern nanodevices.

Hence, the objective of the present work is to study, the structural and electronic properties of Ce-doped $\mathrm{ZnO}$ NPs synthesized through a simple cost-effective chemical sol-gel route. The synthesized heavily doped (Ce, 10 at. \%) sample will be denoted as CZO in present discussion. The synthesized sample was then investigated using X-ray diffraction (XRD) method to understand its structural properties. To study the optical and electronic properties, we use UV-Vis and Photoluminescence (PL) method and finally to analyze the micro-

\footnotetext{
*the_saikat@yahoo.com

saikat.chattopadhyay@jaipur.manipal.edu

The results were presented at the International Conference on Multifunctional Nanomaterials (ICMN2020)
} 
structural properties FESEM images were captured with different magnification range. EDX helps to identify the elements present in the prepared sample. Finally, an attempt has been made to correlate the structural and optical observations to discuss its utility to design modern light emitting or sensor devices.

\section{EXPERIMENTAL DETAILS}

\subsection{Material Synthesis}

Undoped $\mathrm{ZnO}$ and Ce-doped $\mathrm{Zn}_{1-x} \mathrm{Ce}_{x} \mathrm{O}$ (where $x=0$ and 0.1) NPs were synthesized through chemical coprecipitation method. It is very popular and widely used technique to prepare NPs due to its ease of processing and cost effectiveness. The details of the method can be found in our previous report $[4,5]$. A complete flow chart, to understand the adopted chemical synthesis process easily, is given in Fig. 1.

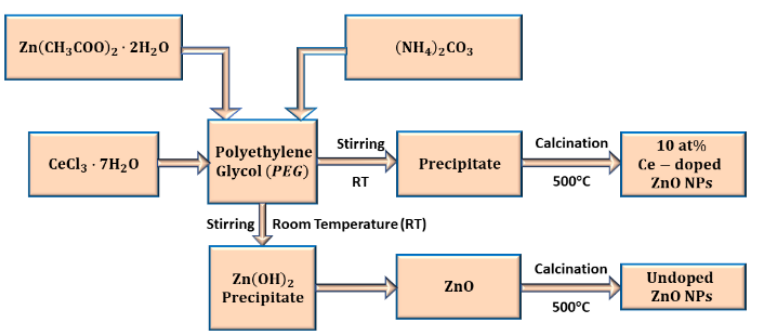

Fig. 1 - Flow chart of the chemical synthesis process of Ce doped $\mathrm{ZnO} \mathrm{NPs}$

\subsection{Characterization Techniques}

To study the structural properties of our prepared powder sample, after a proper heat treatment $\left(500{ }^{\circ} \mathrm{C}\right)$ in oxygen environment for $3 \mathrm{~h}$, we used X-ray diffraction method (Make: PAN analytical Empyrean, Model) with $\mathrm{CuK}_{\alpha}$ radiation of wavelength $1.5418 \AA$ having $\mathrm{Cu}$ anode and $\mathrm{Ni}$ filter following Bragg-Brentano geometry in the wide-angle $(2 \theta)$ region from $25^{\circ}$ to $85^{\circ}$. One can find a complete analysis of our undoped $\mathrm{ZnO}$ sample in our previous report $[4,5]$. The Williamson-Hall (W-H) plots were obtained from the XRD data to determine particle size and the impact of micro-strain on peak broadening.

The FTIR spectroscopy was used to identify the various functional groups present in the samples with a typical Fourier transform infrared spectrometer (Make: Alpha, Bruker, Germany) within a range of 4000$500 \mathrm{~cm}^{-1}$. The UV-Vis spectroscopy of all the samples was carried out using a standard UV-Vis equipment (Make: Shimadzu UV2600, Japan) after dispersing them in ethanol solution followed by sonication for $30 \mathrm{~min}$. The spectra were recorded in transmission mode within the wavelength range of 200 to $600 \mathrm{~nm}$. To study the optical properties, photoluminescence (PL) emission spectra of the sample were recorded using a standard photoluminescence spectrometer (Make: Horiba Fluoromax 4c, Horiba, USA) with an excitation wavelength of $310 \mathrm{~nm}$ and $325 \mathrm{~nm}$. The morphology of sample was observed using field emission scanning electron microscope (FESEM) (Make: JEOL-7610F, Japan). For elemental analysis of the sample, energy dispersive X-ray (EDX) method is adopted.

\section{RESULTS AND DISCUSSION}

\subsection{X-ray Diffraction}

The XRD pattern and its complete analysis of undoped $\mathrm{ZnO} \mathrm{NPs}$ is already reported in our previous publication $[4,5]$. The XRD pattern of $\mathrm{CZO}$ is shown in Fig. 2a. It clearly confirms the hexagonal wurtzite structure with observed prominent crystal peaks like (100), (002), (101), (102), (110), (103), (200), (112), (201), (004) and (202). Here, it is worthy to note that a weak signal corresponding to the crystal plane (111) of cubic $\mathrm{CeO}_{2}$ can be observed at the position $2 \theta=28.64^{\circ}$ which indicates the possibility of partial oxidation of $\mathrm{Ce}^{3+}$ into $\mathrm{Ce}^{4+}$ during the high temperature $\left(500^{\circ}\right)$ annealing process which leads to the formation of $\mathrm{CeO}_{2}$. Major peak positions and interplanar spacing collected from XRD data are listed in Table 1. Doping causes a shift in peak positions towards lower $2 \theta$ angle. It may be a result of the local strain generated due to the doping of $\mathrm{Ce}^{3+}$. It is well-known that $\mathrm{Ce}^{3+}$ have, comparatively a larger ionic radius $(0.103 \mathrm{~nm})$ than $\mathrm{Zn}^{2+}(0.074 \mathrm{~nm})$ [13] and the strain is generated in the NPs when it is replacing $\mathrm{Zn}^{2+}$ ions in $\mathrm{ZnO}$ host lattice to settle down to form a stable structure.
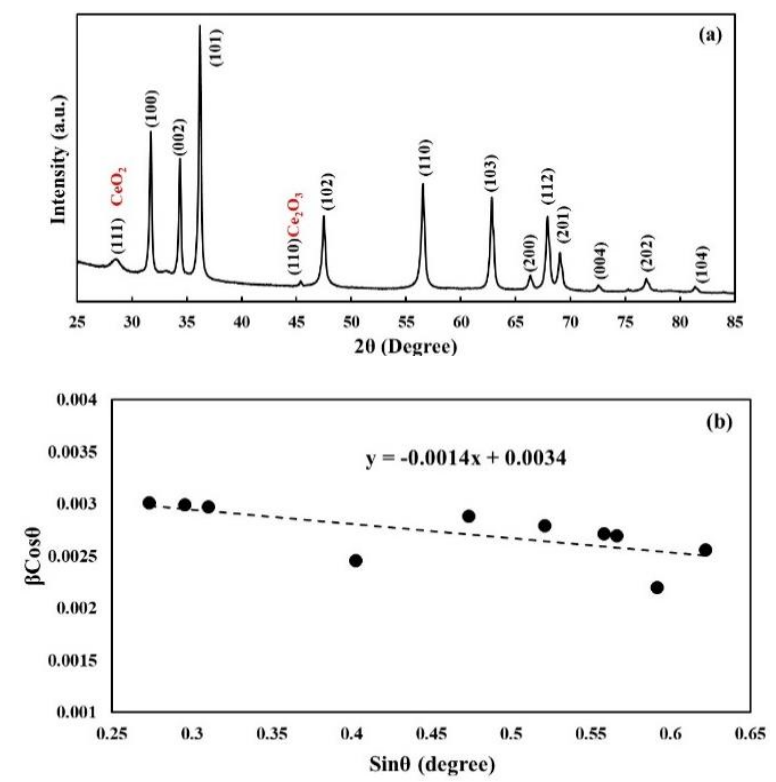

Fig. 2 - (a) XRD patterns of 10 at. \% Ce doped ZnO NPs and (b) Williamson-Hall (W-H) plot of 10 at. \% Ce-doped ZnO NPs

Table 1 - Positions and peak shift of major peaks after doping

\begin{tabular}{|c|c|c|c|}
\hline Sample & \multicolumn{3}{|c|}{ Peaks } \\
\hline & $(100)$ & $(002)$ & $(101)$ \\
\hline $\begin{array}{c}\mathrm{ZnO}(2 \theta) \\
{[4,5]}\end{array}$ & 32.0831 & 34.7757 & 36.4580 \\
\hline $\mathrm{CZO}(2 \theta)$ & 31.7340 & 34.3935 & 36.2172 \\
\hline $\begin{array}{c}d \mathrm{ZnO}(\AA) \\
{[4,5]}\end{array}$ & 2.7876 & 2.5776 & 2.4625 \\
\hline$d \mathrm{CZO}(\AA)$ & 2.8198 & 2.7008 & 2.6076 \\
\hline
\end{tabular}

The orientation parameters $\left(\gamma_{h k l}\right)$ for CZO sample considering three prominent peaks (100), (002) and (101), have been calculated to understand the preferred growth orientation using the formula [14]: 
Table 2 - Orientation parameter, crystallite size, dis-location density, strain, lattice parameters, $u$-value, volume, and bond length calculated from XRD data

\begin{tabular}{|l|l|l|l|}
\hline & $(100)$ & $(002)$ & $(101)$ \\
\hline $\begin{array}{l}\text { Orientation parame- } \\
\text { ter }\left(\gamma_{h k l}\right)\end{array}$ & 0.2744 & 0.2277 & 0.4980 \\
\hline$t_{D S}(\mathrm{~nm})$ & 46.15 & 46.47 & 46.75 \\
\hline $\begin{array}{l}\text { Dislocation density } \\
(\delta)\left(\cdot 10^{14}\right)\left(\mathrm{m}^{-2}\right)\end{array}$ & 4.695 & 4.631 & 4.576 \\
\hline$t_{W H}(\AA)$ & 40.78 & \\
\hline Strain $(\varepsilon)$ & $-0.07 \cdot 10^{-2}$ & \\
\hline$d$-spacing $(\AA)$ & 2.8198 & 2.7008 & 2.6076 \\
\hline$a(\AA)$ & 3.2560 & \\
\hline$c(\AA)$ & 5.4016 & \multicolumn{4}{|l}{} \\
\hline$c / a$ & 1.6589 & 0.3711 \\
\hline$u$-value & 49.5917 & \\
\hline Volume $(\AA)^{3}$ & 2.0047 & \\
\hline Bond length $(\AA)$ &
\end{tabular}

$$
\gamma_{h k l}=I_{h k l} / \sum I_{h k l} .
$$

Here, $I_{h k l}$ represents the intensities of the corresponding crystallographic planes with Miller indices $(h k l)$. Calculated $\gamma_{h k l}$ values for CZO sample are listed in Table 2. The variation of the data indicates a random distribution of crystallographic planes in the sample. The lattice constants $a$ and $c$ are calculated using formula for wurtzite structure of $\mathrm{ZnO}[4,14]$

$$
\frac{1}{d^{2}}=\frac{4}{3}\left(\frac{h^{2}+h k+k^{2}}{a^{2}}\right)+\frac{l^{2}}{c^{2}} .
$$

Both the lattice constants ( $a$ and $c$ ) for CZO sample are larger than undoped $\mathrm{ZnO}$ [4] which is the indication of proper settlement of $\mathrm{Ce}^{3+}$ ions at interstitial sites of the $\mathrm{ZnO}$ host lattice. The $\mathrm{Zn}-\mathrm{O}$ bond length is calculated in this case using the formula $[4,14]$

$$
L=\sqrt{\frac{a^{2}}{3}+\left(\frac{1}{2}-u\right) c^{2}} .
$$

Here,

$$
u=\frac{1}{3}\left(\frac{a^{2}}{c^{2}}\right)+\frac{1}{4}
$$

The particle sizes are calculated along different planes using the well-known Debye-Scherrer formula [4, 14]

$$
t_{D S}=\frac{k \lambda}{\beta \cos \theta},
$$

where $\beta$ is the full width at half maximum (FWHM) of the given peak, $\theta$ is the corresponding angle of Bragg diffraction, $\lambda$ is the wavelength of $\mathrm{X}$-ray used (1.5406 $\mathrm{A}$ ) and $k$ is a constant (value $=0.9$ ). Calculated particle size $\left(t_{D S}\right)$ along different planes is approximately $46 \mathrm{~nm}$ and tabulated in Table 2 . The crystallite sizes confirm uniform nanocrystalline nature of the $\mathrm{CZO}$ samples along all the major planes. Calculated dislocation densities $(\delta h k l)[4,14]$ vary between $\sim 4.65 \cdot 10^{14} \mathrm{~m}^{-2}$ to $\sim 4.576 \cdot 10^{14} \mathrm{~m}^{-2}$ which is as expected. Based on the experimental data, a W-H analysis is done to understand the strain profile using the equation $[4,14]$

$$
\beta \cos \theta=\frac{C \lambda}{t_{W H}}+2 \varepsilon \sin \theta .
$$

Here, $t_{W H}$ is crystallite size, $\varepsilon$ is strain, $\lambda$ is the wavelength used and $\beta$ is FWHM. The constant $C$ is a correction factor, and it is taken as 1 . A graph between $\beta \cos \theta$ and $\sin \theta$ is plotted in Fig. $2 \mathrm{~b}$ for $\mathrm{CZO}$ which is obviously fitted very well as a straight line. From the slopes and intercepts of the linear fit equation, the magnitudes of $t_{W H}$ and $\varepsilon$ are determined. The negative sign indicates the microstrain is compressive in this case. As per our previous report, the microstrain calculated for undoped $\mathrm{ZnO}$ is $-5.19 \cdot 10^{-2}$ [4] which is too higher in comparison to the doped sample. They were simultaneously synthesized and further treated under the same conditions, which further support our claim that the Ce ions after doping settle down properly in the $\mathrm{ZnO}$ matrix, reducing the microstrain.

\subsection{FTIR Analysis}

The Fourier transform infrared (FTIR) spectrum was recorded to explore the chemical bonding of CZO sample. It was recorded between $500-4000 \mathrm{~cm}^{-1}$ in the transmission mode and the results are displayed in Fig. 3. As expected, the vibrational bands observed within $1000 \mathrm{~cm}^{-1}$ are influenced due to the inorganic elements. The presence of Ce ions in the CZO sample was clearly elucidated by the occurrence of a peak at $575 \mathrm{~cm}^{-1}$ [13] and the other infrared absorption bands observed at $678 \mathrm{~cm}^{-1}$ and $833 \mathrm{~cm}^{-1}$ are due to the Ce$\mathrm{O}$ bonding [15]. The stretching modes of $\mathrm{C}-\mathrm{O}$ and $\mathrm{C}=\mathrm{O}$ were observed around $1396 \mathrm{~cm}^{-1}$ and $1524 \mathrm{~cm}^{-1}$ as shown in Fig. 3. [13, 15]. A dip at $2324 \mathrm{~cm}^{-1}$ is a signature of $\mathrm{C}-\mathrm{H}$ groups [15]. No other major bands except those mentioned here are detected in the FTIR spectrum which substantiates that the synthesized nanoparticles are almost pure without any significant trace of impurity other than Ce.

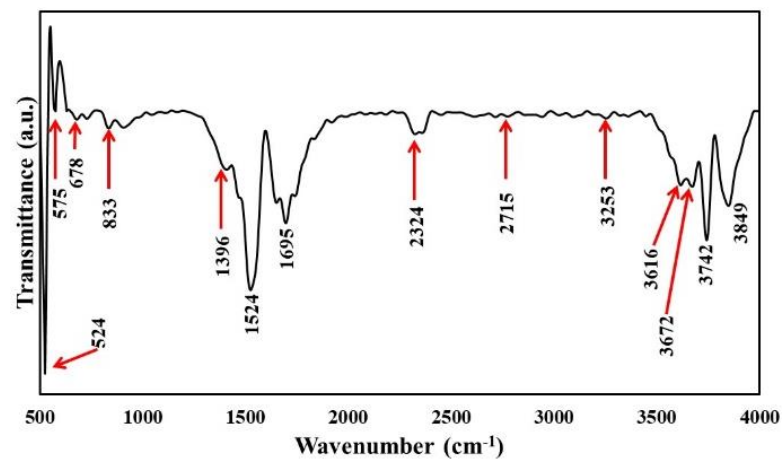

Fig. 3 - FTIR patterns of Ce doped ZnO NPs

\subsection{UV-Vis Spectra and Optical Band Gap Study}

UV-Vis spectra of CZO nanoparticles were recorded in the wavelength range $200-600 \mathrm{~nm}$ at room temperature in transmission mode. The variation is shown in Fig. 4. The CZO sample is highly transparent in nature 


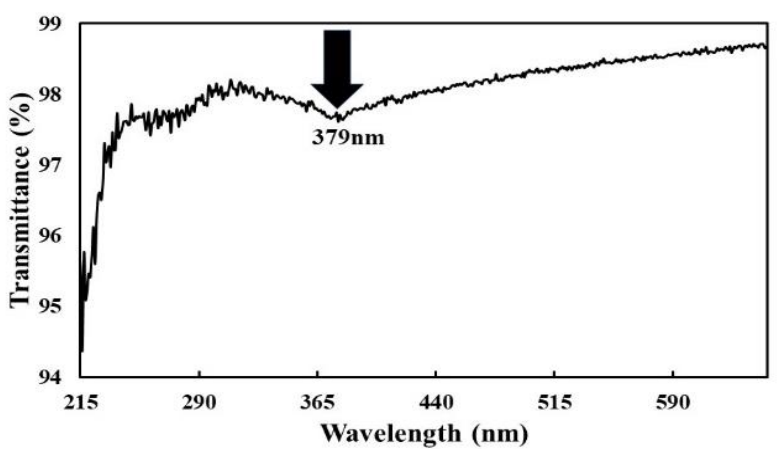

Fig. 4 - UV-Vis spectra of Ce doped ZnO NPs

in the visible region and indicates an absorption dip at $379 \mathrm{~nm}$. The band gap energy $\left(\varepsilon_{g}\right)$ of NPs was calculated using the formula:

$$
\epsilon_{g}=\frac{h c}{\lambda}
$$

where $h$ and $c$ are Planck's constant and speed of light in vacuum, respectively. The calculated band gap energy for our CZO sample is $3.270 \mathrm{eV}$. As expected, it clearly shows a red shift of band gap when compared with an undoped $\mathrm{ZnO}$ NPs (3.294 eV [5]) prepared and measured under same condition. The shift of absorption dip towards the longer wavelength region is due to the doping of rare earth element (Ce) which forms oxygen vacancies and additional energy levels. Ivetíc et al. [16] noticed a similar kind of behavior for Eu doped $\mathrm{ZnO}$ nanostructures. Such red shift may be related to the formation of some shallow level inside the band gap, due to the introduction of impurity atoms $\left(\mathrm{Ce}^{3+}\right)$ into the $\mathrm{ZnO}$ wurtzite lattices structure [13]. In connection to the discussion made by Bomila et al. [13], here it is justified to say that the narrowing of band gap energy due to Ce insertion, is a result of the formation of Ce related, localized, density of states closer to the conduction band minima of $\mathrm{ZnO}$. The existence and connection to the band gap reduction with the formation of such localized electronic states have also been reported and discussed by Kumar et al. [17].

\subsection{Photoluminescence (PL) Study}

PL spectra (Fig. 5) of the sample was recorded by exciting it with two different excitation wavelengths $310 \mathrm{~nm}$ and $325 \mathrm{~nm}$ at room temperature. The spectra (Fig. 5) show a broad peak around $380 \mathrm{~nm}$. It is wellknown in literature that an intense UV peak centered around $382 \mathrm{~nm}$ is identified as near band edge (NBE) emission is an intrinsic property of the wurtzite $\mathrm{ZnO}$ and originates from the excitonic recombination process [18]. Again, in our CZO sample, the absence of a PL emission in the visible range is also considered as a signature of high crystalline sample [18].

\subsection{Micro-structural Study with FESEM}

The surface morphology of CZO NPs is observed by FESEM as represented in Fig. 6 which shows the formation of clusters of CZO NPs with size and morphology. Fig. 6a clearly shows the formation of particle like structure. To understand the mechanism in better way, we captured higher resolution FESEM photographs which clearly indicates the formation of distorted flower petal like self-assembled structures in our CZO sample. The distortion may be due to a heavy Ce doping. To confirm the presence of Ce, we performed EDX study which is shown in Fig. 7 with the elements present in the sample in a tabular form.

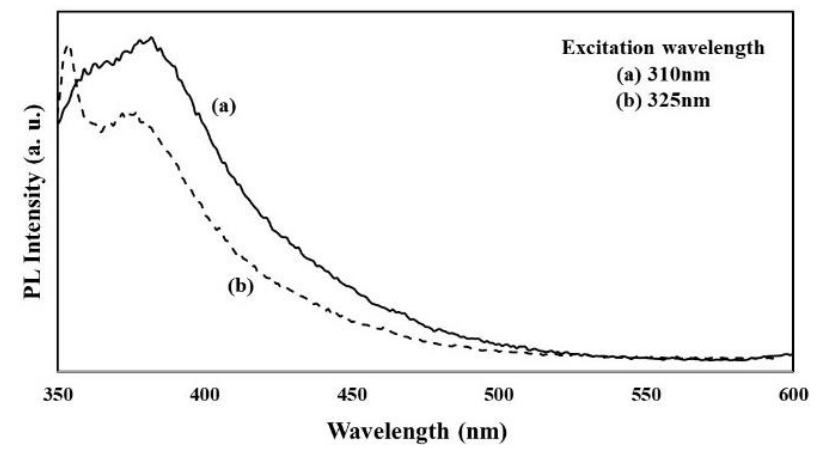

Fig. 5 - Photoluminescence spectrum of Ce doped ZnO NPs
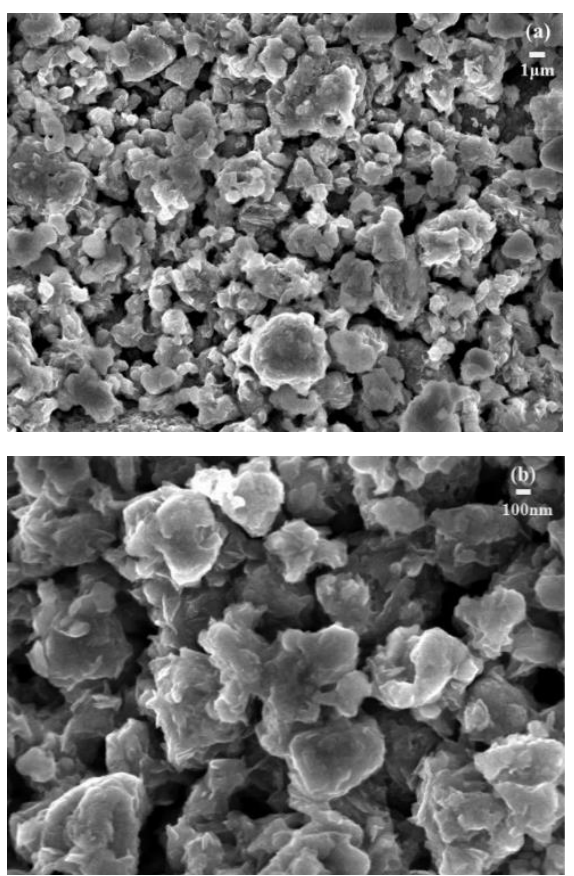

Fig. 6 - FESEM patterns of 10 at. \% Ce doped ZnO NPs

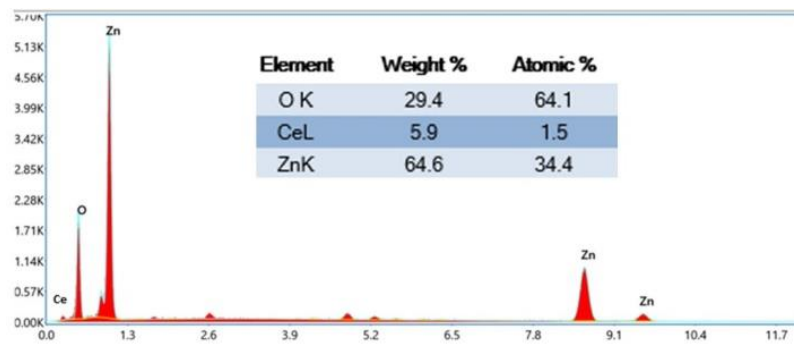

Fig. 7 - EDX of Ce doped ZnO NPs

\section{CONCLUSIONS}

The work explains a simple, low-cost sol-gel method to synthesize $\mathrm{ZnO}$ nanoparticles with heavy Ce doping. Prepared sample shows a XRD peak shift towards lower Bragg's angle as compared to undoped sample. It 
also indicates a lattice distortion due to doping. Small amount of impurity phases in terms of $\mathrm{CeO}_{2}$ and $\mathrm{Ce}_{2} \mathrm{O}_{3}$ are present in prepared samples which is a known fact that only limited $\mathrm{Ce}^{3+}$ ions are soluble in the host $\mathrm{ZnO}$ matrix. FTIR analysis shows the presence of all desired $\mathrm{Zn}-\mathrm{O}$ and $\mathrm{Ce}-\mathrm{O}$ bonds. Band gap analysis shows its lowering due to doping as compared to undoped $\mathrm{ZnO}$. It is because of the defect's states generated during the settlement of dopant in the $\mathrm{ZnO}$ host matrix. As the doped Ce particles have larger ionic radius so the possibility of generation of such defect states is obvious and acceptable. PL emission spectra at two different excitation wavelengths shows an intense UV peak centered around $382 \mathrm{~nm}$ and is identified as NBE emission, a well-known characteristic of a wurtzite $\mathrm{ZnO}$ structure. The FESEM micrographs have distorted flower petal like nanostructures. The distortion is caused by heavy Ce doping. The presence of $\mathrm{Ce}$ in the sample is confirmed by EDX spectra. Overall, the work provides an insight to the features of Ce doped $\mathrm{ZnO}$ NPs which can be useful to design optoelectronic devices with tunable band gap.

\section{ACKNOWLEDGEMENTS}

Authors (SC, KPM) acknowledge the financial grant provided by UGC-DAE-CSR (Mumbai Centre) through a collaborative research scheme (CRS) project (vide letter no. Ref: UDCSR/MUM/AO/CRS-M-316/2020/814 dated July 13; 2020). The authors thank Central Analytical Facility (CAF), Manipal University Jaipur (MUJ), India, for UV-Vis and PL measurements. Sophisticated Analytical Instrumentation Facility (SAIF) of MUJ, India, for FESEM measurements, is duly acknowledged. Mr. Ashok Kumawat expresses gratitude towards Ramdas Pai Scholarship of MUJ, India.

\title{
REFERENCES
}

1. J. Theerthagiri, S. Salla, R.A. Senthil, P. Nithyadharseni, A. Madankumar, P. Arunachalam, T Maiyalagan, H-S Kim, Nanotechnology 30, 392001 (2019).

2. Ü. Özgür, Ya. I. Alivov, C. Liu, A. Teke, M.A. Reshchikov, S. Doğan, V. Avrutin, S.J. Cho, H. Morkoç, J. Appl. Phys. 98, 041301 (2005).

3. K.P. Misra, R.K. Shukla, A. Srivastava, A. Srivastava, Appl. Phys. Lett. 95 No 3, 031901 (2009).

4. S. Chattopadhyay, K.P. Misra, A. Agarwala, A. Rao, P.D. Babu, Mater. Chem. Phys. 227, 236 (2019).

5. K.P. Misra, S. Jain, A. Agarwala, N. Halder, S. Chattopadhyay, Semiconductors 54 No 3, 311 (2020).

6. P. Das Gupta, S. Chattopadhyay, R.J. Choudhary, D.M. Phase, P. Sen, Mater. Lett. 65 No 13, 2073 (2011).

7. R. Röder, S. Geburt, M. Zapf, D. Franke, M. Lorke, T. Frauenheim, A.L. da Rosa, C. Ronning, Phys. Status Solidi B 256, 1800604 (2019).

8. A.L. He, X.Q. Wang, R.Q. Wu, Y.H. Lu, Y.P. Feng, J. Phys.: Condens. Matt. 22 No 17, 175501 (2010).

9. T.M. Schmidt, R.H. Miwa, A. Fazzio, Phys. Rev. B: Condens. Matter. 81 No 19, 195413 (2010).

10. F.-B. Zheng, C.-W. Zhang, P.-J. Wang, H.-X. Luan, Solid State Commun. 152 No 14, 1199 (2012).

11. C. Tan, D. Xu, K. Zhang, X. Tian, W. Cai, J. Nanomater. 215, 329570 (2015).

12. C. Jayachandraiah, G. Krishnaiah, J. Mater Sci. 52, 7058 (2017).

13. R. Bomila, S. Srinivasan, A. Venkatesan, B. Bharath, K. Perinbam, Mater. Res. Innovations 22 No 7, 379 (2017).

14. S. Chattopadhyay, K.P. Misra, A. Agarwala, A. Shahee, S. Jain, N. Halder, A. Rao, P.D. Babu, M. Saran, A.K. Mukhopadhyay, Ceram Int. 45, 23341 (2019).

15. Md. Elias, Md.K. Amin, S.H. Firoz, Md.A. Hossain, S. Akter, Md.A. Hossain, Md.N. Uddin, I.A. Siddiquey, Ceram Int. 43, 84 (2017).

16. T.B. Iveti'c, M.R. Dimitrievska, I.O. G'uth, Lj.R. Da`canin, S.R. Luki'c-Petrovi'c, J. Res. Phys. 36 No 1, 43 (2012)

17. D.R. Kumar, K.S. Ranjith, R.T.R. Kumar, Optik 154, 115 (2018).

18. J.L. Cervantes-López, R. Rangel, J. Espino, E. Martínez, R. García-Gutiérrez, P. Bartolo-Pérez, J.J. Alvarado-Gil, O.E. Contreras, Appl. Phys. A 123, 86 (2017).

\section{Зменшення забороненої зони та утворення пелюсткової наноструктури в нанопорошках $\mathrm{ZnO}$, сильно легованих Сe}

\author{
Kamakhya Prakash Misraํㅜ, Ashok Kumawat ${ }^{1}$, Priyanka Kumari², Susruta Samanta ${ }^{2}$, \\ Nilanjan Halder ${ }^{1}$, Saikat Chattopadhyay ${ }^{1}$
}

\footnotetext{
${ }^{1}$ Department of Physics, School of Basic Sciences, Manipal University Jaipur, Jaipur, Rajasthan 303007, India

2 Department of Chemistry, School of Basic Sciences, Manipal University Jaipur, Jaipur, Rajasthan 303007, India
}

\begin{abstract}
Метою дослідження е вивчення структурної та оптичної поведінки системи наночастинок $\mathrm{ZnO}$, сильно легованих Се. Для синтезу наночастинок застосовано добре відомий хімічний метод золь-гелю та охарактеризовано ї структурні, оптичні та морфологічні особливості. Рентгенографічний аналіз (XRD) та енергодисперсійна рентгенівська спектроскопія (EDX) підтверджують наявність атома Се у підготовленому зразку. Дані XRD підтверджують, що іони $\mathrm{Ce}^{3+}$ займають місця іонів $\mathrm{Zn}^{2+}$ у гексагональній решітці $\mathrm{ZnO}$ під час легування. Завдяки більш високій концентрації легування надлишок Се показуе присутність змішаних фаз $\mathrm{CeO}_{2}$ та $\mathrm{Ce}_{2} \mathrm{O}_{3}$ у зразку. Аналіз Вільямсона-Хола допомагае отримати профіль мікродеформації у вирощеному зразку. Дослідження UV-Vis підтверджуе зміщення забороненої зони в легованих зразках, а дослідження фотолюмінесценції вказуе на наявність дефектних станів, які є причиною переходів поблизу країв зони у зразках. Підготовлені зразки також характеризували за допомогою FESEM для аналізу морфології поверхні та нанокристалічних структур.
\end{abstract}

Ключові слова: ZnO, Рідкоземельний матеріал, Легування, Наночастинки, Заборонена зона, Фотолюмінесценція. 